Correspondence

Kaarina Sivonen

kaarina.sivonen@helsinki.fi

\section{Phylogenetic and morphological evaluation of the genera Anabaena, Aphanizomenon, Trichormus and Nostoc (Nostocales, Cyanobacteria)}

\author{
Pirjo Rajaniemi, ${ }^{1}$ Pavel Hrouzek, ${ }^{2}$ Klára Kaštovská, ${ }^{3}$ \\ Raphaël Willame, ${ }^{4}$ Anne Rantala, ${ }^{1}$ Lucien Hoffmann, ${ }^{4}$ \\ Jiř́ Komárek ${ }^{2,5}$ and Kaarina Sivonen ${ }^{1}$
}

\author{
${ }^{1}$ Department of Applied Chemistry and Microbiology, Viikki Biocenter, PO Box 56, Fl-00014 \\ University of Helsinki, Finland \\ ${ }^{2}$ University of South Bohemia, Faculty of Biological Sciences, Branišovská 31, Cz-370 05 \\ České Budějovice, Czech Republic \\ ${ }^{3}$ Institute of Hydrobiology, Academy of Sciences of the Czech Republic, Na sádkách 7, Cz-370 \\ 05 České Budějovice, Czech Republic \\ ${ }^{4}$ Public Research Center - Gabriel Lippmann, Environment and Biotechnologies Research Unit, \\ 162a avenue de la Faïencerie, L-1511 Luxembourg, Grand-duchy of Luxembourg \\ ${ }^{5}$ Institute of Botany, Academy of Sciences of the Czech Republic, Dukelská 145, Cz-379 82 \\ Třeboń, Czech Republic
}

\begin{abstract}
The heterocytous cyanobacteria form a monophyletic group according to 16S rRNA gene sequence data. Within this group, phylogenetic and morphological studies have shown that genera such as Anabaena and Aphanizomenon are intermixed. Moreover, the phylogeny of the genus Trichormus, which was recently separated from Anabaena, has not been investigated. The aim was to study the taxonomy of the genera Anabaena, Aphanizomenon, Nostoc and Trichormus belonging to the family Nostocaceae (subsection IV.I) by morphological and phylogenetic analyses of $16 \mathrm{~S}$ rRNA gene, $r p o B$ and $r b c L X$ sequences. New strains were isolated to avoid identification problems caused by morphological changes of strains during cultivation.

Morphological and phylogenetic data showed that benthic and planktic Anabaena strains were intermixed. In addition, the present study confirmed that Anabaena and Aphanizomenon strains were not monophyletic, as previously demonstrated. The evolutionary distances between the strains indicated that the planktic Anabaena and Aphanizomenon strains as well as five benthic Anabaena strains in cluster 1 could be assigned to a single genus. On the basis of the 16S rRNA, $r p o B$ and $r b c L X$ gene sequences, the Anabaena/Aphanizomenon strains (cluster 1 ) were divided into nine supported subclusters which could also be separated morphologically, and which therefore might represent different species. Trichormus strains were morphologically and phylogenetically heterogeneous and did not form a monophyletic cluster. These Trichormus strains, which were representatives of three distinct species, might actually belong to three genera according to the evolutionary distances. Nostoc strains were also heterogeneous and seemed to form a monophyletic cluster, which may contain more than one genus. It was found that certain morphological features were stable and could be used to separate different phylogenetic clusters. For example, the width and the length of akinetes were useful features for classification of the Anabaena/Aphanizomenon strains in cluster 1. This morphological and phylogenetic study with fresh isolates showed that the current classification of these anabaenoid genera needs to be revised.
\end{abstract}




\section{INTRODUCTION}

Heterocytous cyanobacteria consistently form a monophyletic cluster among cyanobacteria on the basis of their 16S rRNA gene sequences (Wilmotte, 1994; Turner, 1997, 1999; Wilmotte \& Herdman, 2001; Lyra et al., 2001), RFLP and genomic fingerprinting (Lyra et al., 2001) and nifD sequences (Henson et al., 2004). This monophyletic cluster contains the orders Nostocales and Stigonematales (Sections IV and V) (Rippka et al., 1979), which were found to be intermixed (Turner et al., 1997, 1999; Gugger \& Hoffmann, 2004; Henson et al., 2004). However, the genera Anabaena Born. et Flah., Aphanizomenon Born. et Flah., Nostoc Born. et Flah. and Cylindrospermopsis Seen. et Subba Raju clustered together within these orders in a $16 \mathrm{~S}$ rRNA tree (Gugger \& Hoffmann, 2004).

Currently, the genera Anabaena, Aphanizomenon, Trichormus (Born. et Flah.) Kom. et Anag. and Nostoc belong to order Nostocales, family Nostocaceae by traditional classification (Komárek \& Anagnostidis, 1989) and subsection IV.I by bacteriological classification (Rippka et al., 2001a). Identification of these genera is based on morphological features such as morphology of the filament, vegetative cells, heterocytes (heterocysts) and akinetes (Komárek \& Anagnostidis, 1989). The form of the colony, shape of terminal cells, presence of sheath and gas vesicles, as well as life cycle, are additional features used for the identification of some genera. Recently, Trichormus was separated from the traditional genus Anabaena on the basis of akinete development and was transferred into the subfamily Nostocoidae. According to this revision, the species Anabaena variabilis, Anabaena azollae and Anabaena doliolum belong to the genus Trichormus (Komárek \& Anagnostidis, 1989). The phylogeny of the Trichormus strains has not been studied. The assignment of some species either to Anabaena or to Aphanizomenon has been discussed (Komárek \& Anagnostidis, 1989; Komárek \& Kováčik, 1989). Also, the previous phylogenetic studies of Lyra et al. (2001), Gugger et al. (2002b) and Iteman et al. (2002) have shown that the genera Anabaena and Aphanizomenon are not monophyletic. Furthermore, the separation of the genera Nostoc and Anabaena has also been discussed in recent years (Henson et al., 2002; Tamas et al., 2000).

Phylogenetic studies of cyanobacteria have demonstrated that genetic relationships sometimes conflict with the morphological classification (Lyra et al., 2001; Iteman et al., 2002; Gugger \& Hoffmann, 2004). The comparison of morphological and genetic data is hindered by the lack of cultures of several cyanobacterial morphospecies and inadequate morphological data of sequenced strains. Moreover, some strains may lose some important features such as gas vesicles (Lehtimäki et al., 2000) or form of colony (Gugger et al., 2002b) during long-term laboratory cultivation, which complicates identification. Komárek \& Anagnostidis (1989) have estimated that more than $50 \%$ of the strains in culture collections are misidentified.
Therefore, new isolates should be studied by combined morphological and genetic approaches.

This study focused on the combined genetic and phenotypic relationships of the four genera Nostoc, Trichormus, Anabaena and Aphanizomenon. We isolated new Anabaena, Aphanizomenon and Nostoc strains. Detailed morphological analyses of these strains were carried out at the time of isolation in order to avoid difficulties in identification. The phylogeny of the strains was investigated by sequencing two housekeeping genes, $16 \mathrm{~S}$ rRNA and $r p o B$, as well as a carbon-fixation-associated gene, $r b c L X$.

\section{METHODS}

Strains and cultivation. The 51 Anabaena, Aphanizomenon, Trichormus and Nostoc strains studied were unialgal, but not axenic (Table 1). The morphology of the strains with a few exceptions was analysed in this study. The morphology of Nostoc muscorum, Nostoc calcicola, Nostoc ellipsosporum and Nostoc edaphicum was described previously by Hrouzek et al. (2003) and Anabaena compacta ANACOM-KOR by Zapomĕlová (2004). The morphology of strain Anabaena sp. 277 (Lyra et al., 2001; Gugger et al., 2002a) was reevaluated because of its clustering with Aphanizomenon issatschenkoi strains in the phylogenetic trees.

For morphological studies, the strains were cultivated in BG11 medium (Stanier et al., 1971) at $18-22^{\circ} \mathrm{C}$ under a light intensity of $30 \mu \mathrm{mol} \mathrm{m} \mathrm{m}^{-2} \mathrm{~s}^{-1}$. For DNA extraction, the strains were cultivated in Z8 medium (Zehnder in Staub, 1961; Kotai, 1972) without nitrogen at $18 \cdot 5-21 \cdot 5{ }^{\circ} \mathrm{C}$ under a light intensity of $10 \mu \mathrm{mol} \mathrm{m}{ }^{-2} \mathrm{~s}^{-1}$.

Morphological study. The morphology of cells and filaments was studied using an Olympus CX 40 light microscope with a digital camera. Olympus DP SOFT version 4.0 software was used for image analysis. The following parameters were selected to describe the morphology of the studied strains: length and width of vegetative cells, heterocytes and akinetes; morphology of terminal cell; distance between heterocytes and distance between a heterocyte and the nearest akinete (counted as the number of cells); presence or absence of terminal heterocytes and gas vesicles; and shape of filament and its aggregation in colonies.

Statistical evaluation of morphological data. The mean values of measured morphological parameters were compared with oneway analysis of variance (ANOVA) followed by the Tukey honest significant difference (HSD) test in Statistica for Windows 4. To describe the variability of all morphological data and to evaluate the importance of measured morphological features, principalcomponent analysis (PCA) was carried out in Canoco for Windows 4.5 (ter Braak \& Šmilauer, 1998). The program CanoDraw 4.5 was used for construction of the PCA plot.

DNA extraction. Cells were harvested by filtration through 1 or $5 \mu \mathrm{m}$ Poretics filters (Osmonic) and stored at $-20^{\circ} \mathrm{C}$. DNA was extracted by the modified CTAB method (Hönerlager et al., 1995; Gkelis et al., 2005). Filters containing cells were mechanically lysed using lysis matrix A and a Fast-prep instrument (Bio101) in $500 \mu \mathrm{l}$ extraction buffer $[100 \mathrm{mM}$ Tris/ $\mathrm{HCl}, \mathrm{pH} 7 \cdot 5,1.5 \%$ (w/v) SDS, $10 \mathrm{mM}$ EDTA, $1 \%(\mathrm{w} / \mathrm{v})$ deoxycholate, $1 \%(\mathrm{v} / \mathrm{v})$ IGEPAL CA-630 (Sigma), $5 \mathrm{mM}$ thiourea and $10 \mathrm{mM}$ dithiothreitol, according to Hönerlager et al., 1995] for $30 \mathrm{~s}$ at speed 5. The extracts were centrifuged at $10000 \mathrm{~g}$ for $1 \mathrm{~min}$ and the DNA-containing supernatants were incubated in $5 \mathrm{M} \mathrm{NaCl} / 10 \%$ (w/v) CTAB at $65^{\circ} \mathrm{C}$ for $20 \mathrm{~min}$, followed by chloroform purification and ethanol precipitation. 
Table 1. Cyanobacterial strains used in this study, their origin and potential ability to produce microcystins

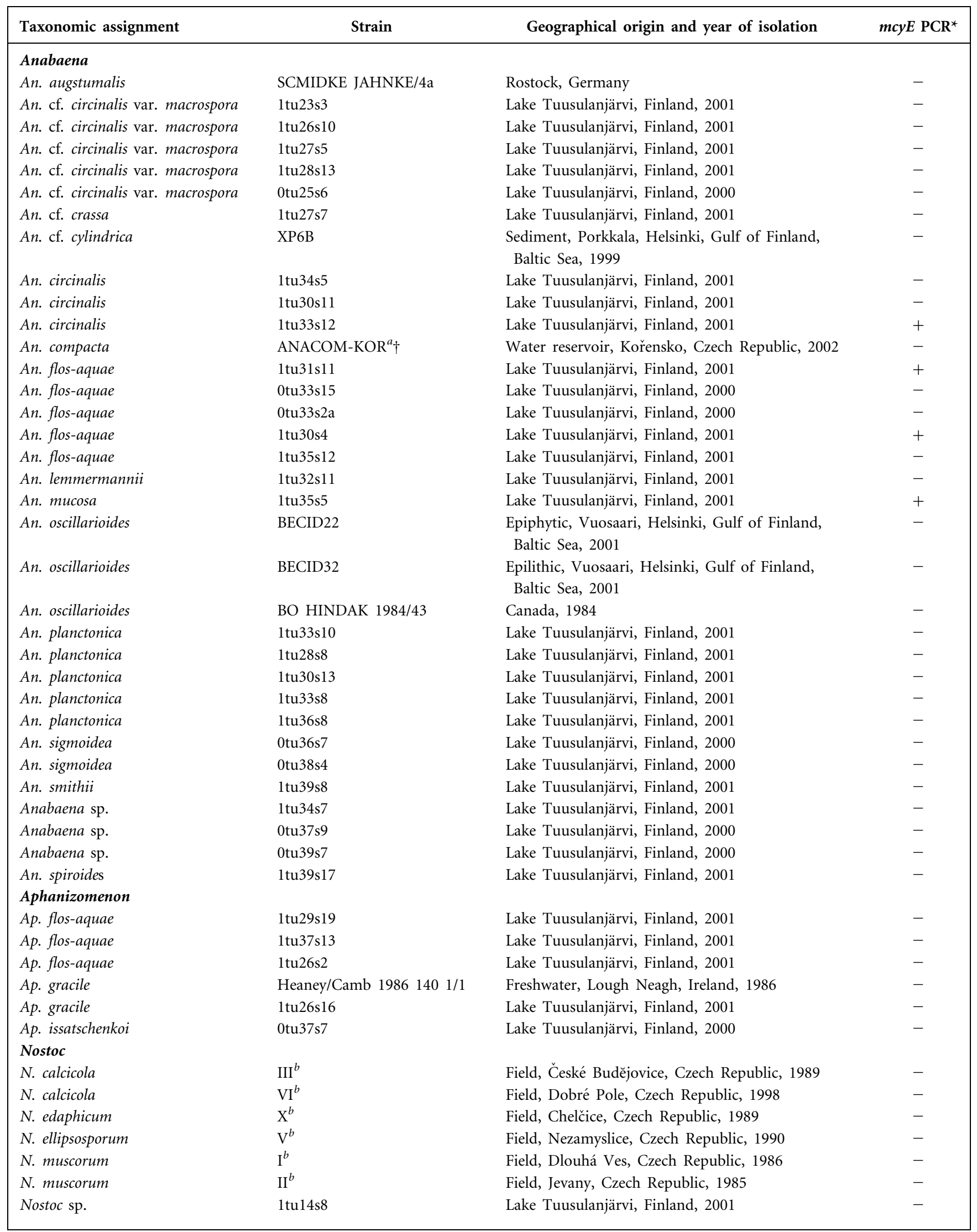


Table 1. cont.

\begin{tabular}{|lll|}
\hline Taxonomic assignment & \multicolumn{1}{c|}{ Strain } & Geographical origin and year of isolation \\
\hline Trichormus & & \\
T. azollae & BAI/1983 & Unknown, 1983 \\
T. doliolum & 1 & Unknown \\
T. variabilis & GREIFSWALD & Unknown, 1992 \\
T. variabilis & HINDAK 2001/4 & Soil, Dombay valley, Caucasus mountains, \\
& & Russian Federation, 2001 \\
& & \\
\hline
\end{tabular}

${ }^{*}$ Determined by PCR with $m c y E$ gene-specific primers.

$†$ Strain described previously by Hrouzek et al. (2003) (a) or Zapomĕlová (2004) (b).

PCR and sequencing. The $16 \mathrm{~S}$ rRNA gene and ITS region were amplified with primers pA (5'-AGAGTTTGATCCTGGCTCAG-3') (Edwards et al., 1989) and B23S (5'-CTTCGCCTCTGTGTGCCTAGGT-3') (Lepère et al., 2000) as described in Gkelis et al. (2005). The 16S rRNA gene (1432-1439 bp) was sequenced with internal sequencing primers $16 \mathrm{~S} 545 \mathrm{R}, 16 \mathrm{~S} 1092 \mathrm{R}$ and $16 \mathrm{~S} 979 \mathrm{~F}$. The $r b c L X$ gene region was amplified and sequenced (782-1003 bp) with primers CX (5'-GGCGCAGGTAAGAAAGGGTTTCGTA- $\left.3^{\prime}\right)$ and CW (5' CGTAGCTTCCGGTGGTATCCACGT-3') as described by Rudi et al. (1998). Despite several trials, amplification of N. muscorum strains was not successful and sequences were not obtained. Amplification of the partial $r p o B$ gene was performed with primer pair rpoBF $\left(5^{\prime}\right.$ GTAGTTGTARCCNTCCCA- $\left.3^{\prime}\right)$ and rpoBR (5'-RCMGCMGACGAAGAAGACG- $3^{\prime}$ ) or primer pair rpoBanaF (5'-AGCMACMGGTGACGTTCC- $3^{\prime}$ ) and rpoBanaR (5'-CNTCCCARGGCATATAGGC-3'), which were designed in this study. For the rpoBF-rpoBR primer pair, amplification was carried out in $50 \mu 11 \times$ DyNAzyme buffer containing $1.6 \mathrm{U}$ DyNAzyme polymerase (Finnzymes), $0.2 \mathrm{mM}$ each dNTP, $0 \cdot 2 \mu \mathrm{M}$ primers and $0 \cdot 5 \mu \mathrm{l}$ target DNA. PCR amplification consisted of initial denaturation for $5 \mathrm{~min}$ at $94^{\circ} \mathrm{C}, 30$ cycles of amplification: $1 \mathrm{~min}$ at $94^{\circ} \mathrm{C}, 1.5 \mathrm{~min}$ at $50^{\circ} \mathrm{C}$ and $2 \mathrm{~min}$ at $72{ }^{\circ} \mathrm{C}$, and a final elongation for $7 \mathrm{~min}$ at $72{ }^{\circ} \mathrm{C}$. For the rpoBanaFrpoBanaR primer pair, $0.8 \mathrm{U}$ Super Taq Plus polymerase (HT Biotechnology LTA) and $1 \times$ Super Taq Plus buffer (HT Biotechnology LTA) replaced DyNAzyme polymerase and buffer, $1 \mathrm{mg}$ BSA $\mathrm{ml}^{-1}$ was added and elongation steps of PCR were performed at $68^{\circ} \mathrm{C}$. The $r p o B$ fragments of strains 1 tu28s8, 1tu33s10, 1tu30s 13 and 1 tu33s 12 were cloned with InsT/Aclone PCR product cloning kit (Fermentas) in order to get high-quality sequences. The $r p o B$ gene fragment (520-635 bp) was sequenced with the primers used in the amplification. In addition to studied strains, 13 reference strains, Anabaena sp. PCC 7108, 14, 123 and 277; Anabaena flosaquae 202A1, Anabaena lemmermannii 66A, Aphanizomenon sp. TR183 and 202; Aphanizomenon flos-aquae PCC 7905, Nostoc punctiforme PCC 72102 and Nodularia sp. HEM, HKVV and PCC 7804, were amplified and sequenced. Sequencing of all genes was performed with an Applied Biosystems Big Dye Terminator cycle sequencing kit and 3700 sequencer at Genome Express (Meylan, France) or with an Applied Biosystems PRISM 310 sequencer according to the manufacturer's instructions. The potential microcystin production of strains was based on the detection of the $m c y E$ gene in PCR with the specific primers mcyE-F2 and mcyE-R4 as described by Rantala et al. (2004).

Phylogenetic analysis. Sequences were aligned in the program ARB (http://www.arb-home.de). The alignment was edited manually and ambiguous bases and hypervariable regions were removed. The highly variable intergenic spacer region between $r b c L$ and $r b c X$ genes as well as the variable indel region in $r p o B$ (positions 322-477 in the alignment) did not allow reliable alignment, and therefore these regions were excluded from the analysis. The $r b c L X$ and $r p o B$ sequences were studied based on three datasets: one containing all codon positions, one containing only the first and second codon positions of $r b c L X$ or $r p o B$ genes and a third containing translated amino acid sequences. Only minor differences were found in a comparison of the datasets and the few conflicting nodes had bootstrap support below $65 \%$. Resolution of clusters and bootstrap values were higher when the third codon positions were included. Therefore, the analysis of $r p o B$ and $r b c L X$ shown here included all codon positions of the genes. Altogether, $1393 \mathrm{bp}$ of the $16 \mathrm{~S}$ rRNA gene, $606 \mathrm{bp}$ of $r b c L X$ and $451 \mathrm{bp}$ of $r p o B$ were used for sequence analysis. Trees based on the $16 \mathrm{~S}$ rRNA gene, $r b c L X$ and $r p o B$ were constructed by neighbour-joining (NJ) (Saitou \& Nei, 1987) and maximum-parsimony (MP) algorithms in the program PAUP ${ }^{*} \mathrm{v} 10 \mathrm{~b}$ (Swofford, 2003) and by the maximum-likelihood (ML) algorithm in PHYLIP v3.6 (Felsenstein, 1993). For NJ, the evolutionary model of substitution was evaluated by the program MODELTEST v.3.06 (Posada \& Crandall, 1998). The GTR $+\mathrm{I}+\mathrm{G}, \operatorname{TrN}+\mathrm{I}+\mathrm{G}$ and SYM $+\mathrm{I}+\mathrm{G}$ evolutionary models of substitution were found to fit the data best for the $16 \mathrm{~S}$ rRNA gene, $r b c L X$ and $r p o B$, respectively. The parameters (base frequencies, rate matrix of substitution types and shape of gamma distribution) were estimated from the data. For NJ and MP analysis, 1000 bootstrap replicates were performed. For ML analysis, only 10 bootstrap replicates were performed due to limited computing power. In addition to these analyses, $\mathrm{GTR}+\mathrm{G}+\mathrm{I}$ evolutionary distances based on the 16S rRNA gene were analysed non-hierarchically with PCA in the program CAP (PISCES). Kishino-Hasegawa (Kishino \& Hasegawa, 1989), Templeton (Templeton, 1983) and Winning-Sites tests (Prager \& Wilson, 1988) were used to compare the alternative phylogenetic trees based on $16 \mathrm{~S}$ rRNA gene sequences. The monophyly of planktic Anabaena/Aphanizomenon, only Aphanizomenon and only planktic Anabaena sequences as well as subclusters A, F and G were tested as implemented in PAUP ${ }^{\star}$ v10b (Swofford, 2003).

\section{RESULTS AND DISCUSSION}

\section{Phenotypic analysis of the strains}

The 51 strains studied were morphologically heterogeneous. Most of them were planktic Anabaena and Aphanizomenon strains that were identified as belonging to three Aphanizomenon species, Aphanizomenon flos-aquae Ralfs ex Born. et Flah., Aphanizomenon gracile (Lemm.) Lemm. and Aphanizomenon issatschenkoi (Usač) Prošk.-Lavr., and 10 Anabaena species: Anabaena crassa (Lemm.) Kom.-Legn. et CronB., Anabaena circinalis Rabenh. ex Born. 
Table 2. Selected morphological characteristics of the studied cyanobacterial strains

The morphology of Nostoc muscorum, N. calcicola, N. ellipsosporum and N. edaphicum was described previously by Hrouzek et al. (2003).

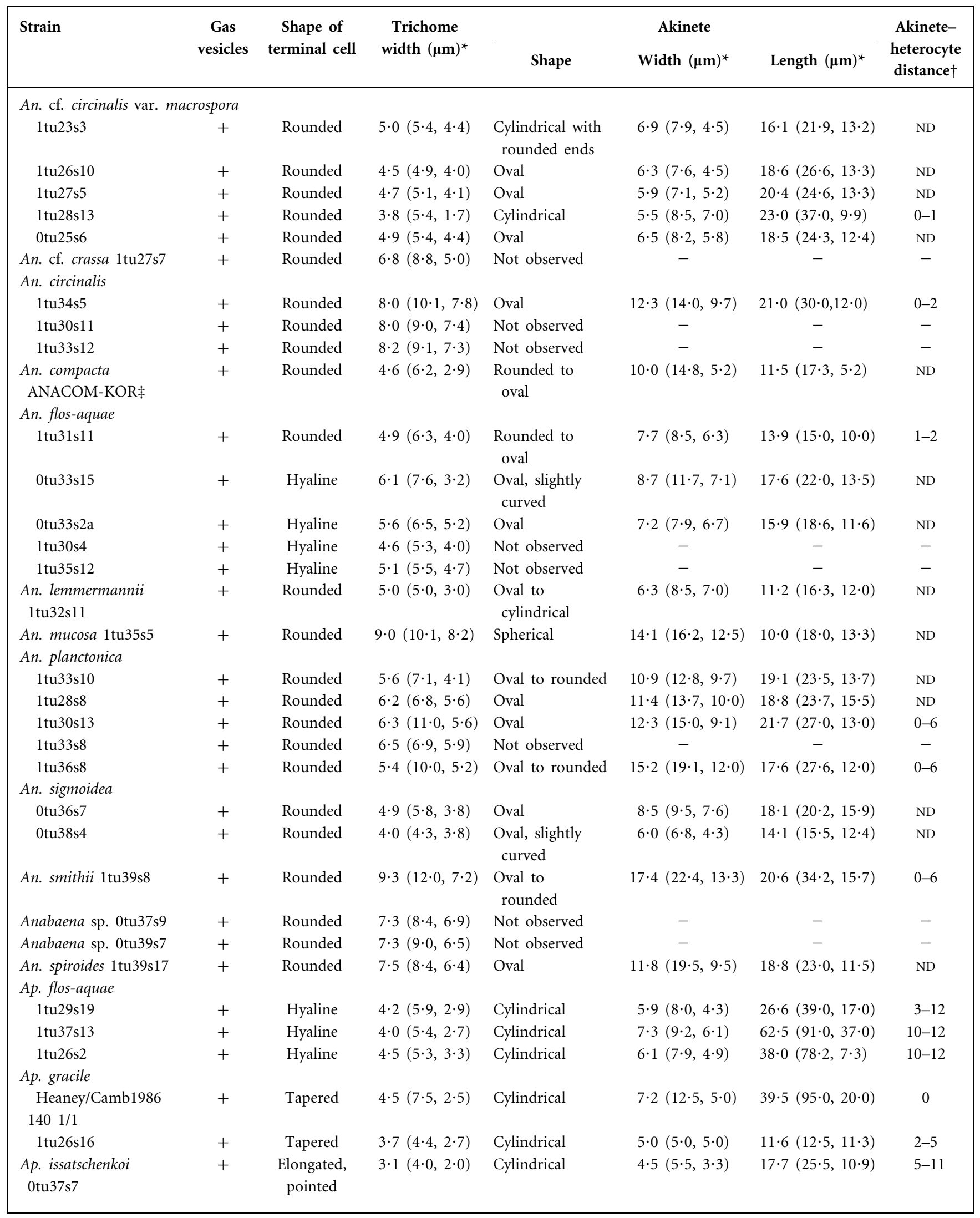


Table 2. cont.

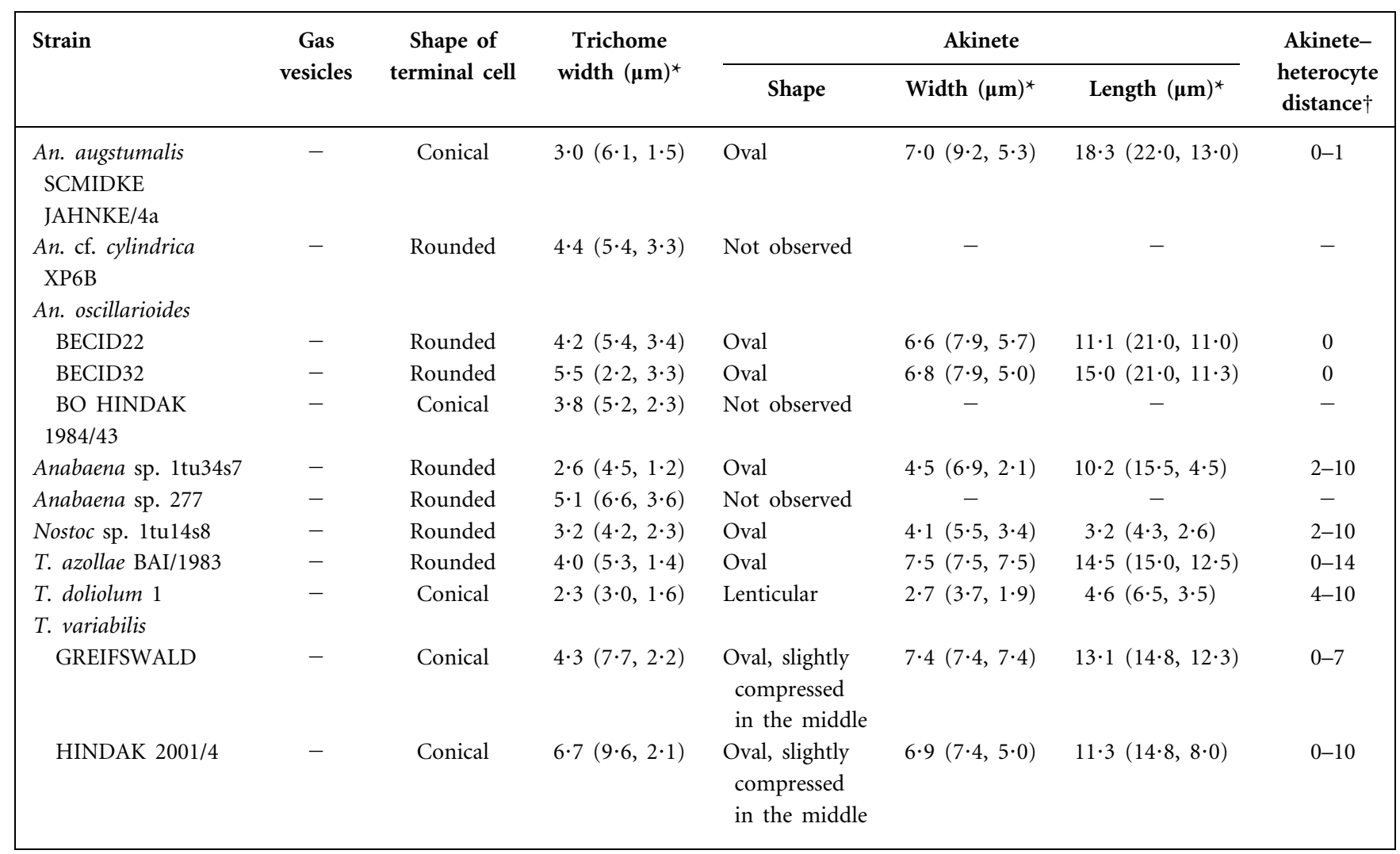

${ }^{*}$ Numbers are means (maximum and minimum values).

$\dagger$ Presented as a number of cells between heterocyte and akinete.

$\ddagger$ Described by Zapomĕlová (2004).

et Flah., Anabaena planctonica Brunnth., Anabaena mucosa Kom.-Legn. et Eloranta, Anabaena spiroides Kleb., Anabaena smithii (Kom.) M. Watan., Anabaena sigmoidea Nyg., Anabaena flos-aquae [Lyngb.] Bréb. ex Born. et Flah., Anabaena cf. circinalis var. macrospora and Anabaena lemmermannii Richt., according to traditional morphological criteria (Geitler, 1932; Desikachary, 1959; Komárek \& Anagnostidis, 1989). In addition, nine benthic strains were identified as Anabaena oscillarioides Bory ex Born. et Flah., Anabaena cf. cylindrica Lemm., Anabaena augstumalis Scmidle, Trichormus variabilis (Born. et Flah.) Kom. et Anag., Trichormus azollae (Strasb.) Kom. et Anag., Trichormus doliolum (Bharadw.) Kom. et Anag. and Nostoc sp. according to traditional morphological criteria. Heterocytes were present in all strains, whereas akinetes were not observed in 12 of the strains studied (Table 2). Aphanizomenon flos-aquae strains lost their fascicle-like colony structure during laboratory cultivation. The morphological characteristics of the strains are summarized in Table 2. Other morphological characters measured are available as supplementary material in IJSEM Online. Microphotographs of the selected strains and their important features are shown in Figs 1 and 2.

Aphanizomenon and Anabaena strains differed significantly by the mean width of vegetative cells, although the width of vegetative cells of some Anabaena (e.g. Anabaena cf. circinalis var. macrospora 1tu28s13) and Aphanizomenon strains was overlapping. Generally, the variability in width and length of vegetative cells, heterocytes and akinetes was high (Table 2), which complicates the use of these characters for identification and separation of Anabaena and Aphanizomenon. These genera were also distinguished by the morphology of the end cells of the trichome which was rounded to oval in planktic Anabaena strains and elongated-hyaline to tapered in Aphanizomenon strains.

Aphanizomenon strains had more or less straight trichomes, slightly constricted at the cross-walls, and their vegetative cells were from barrel-shaped to cylindrical (Fig. 1). The Aphanizomenon issatschenkoi strain was clearly distinguishable from the other Aphanizomenon strains by elongated and pointed terminal cells (Table 2; Fig. 1j, k). Aphanizomenon flos-aquae strains were characterized by hyaline end cells, cylindrical and long akinetes (up to $91 \mu \mathrm{m}$ ) and a long distance between the heterocytes and akinetes (Table 2; Fig. 1d, e). Aphanizomenon gracile trichomes were slightly tapered, but not pointed, and differed from Aphanizomenon flos-aquae by the absence of long hyaline end cells and shorter akinetes (Table 2; Fig. 1i, h). 

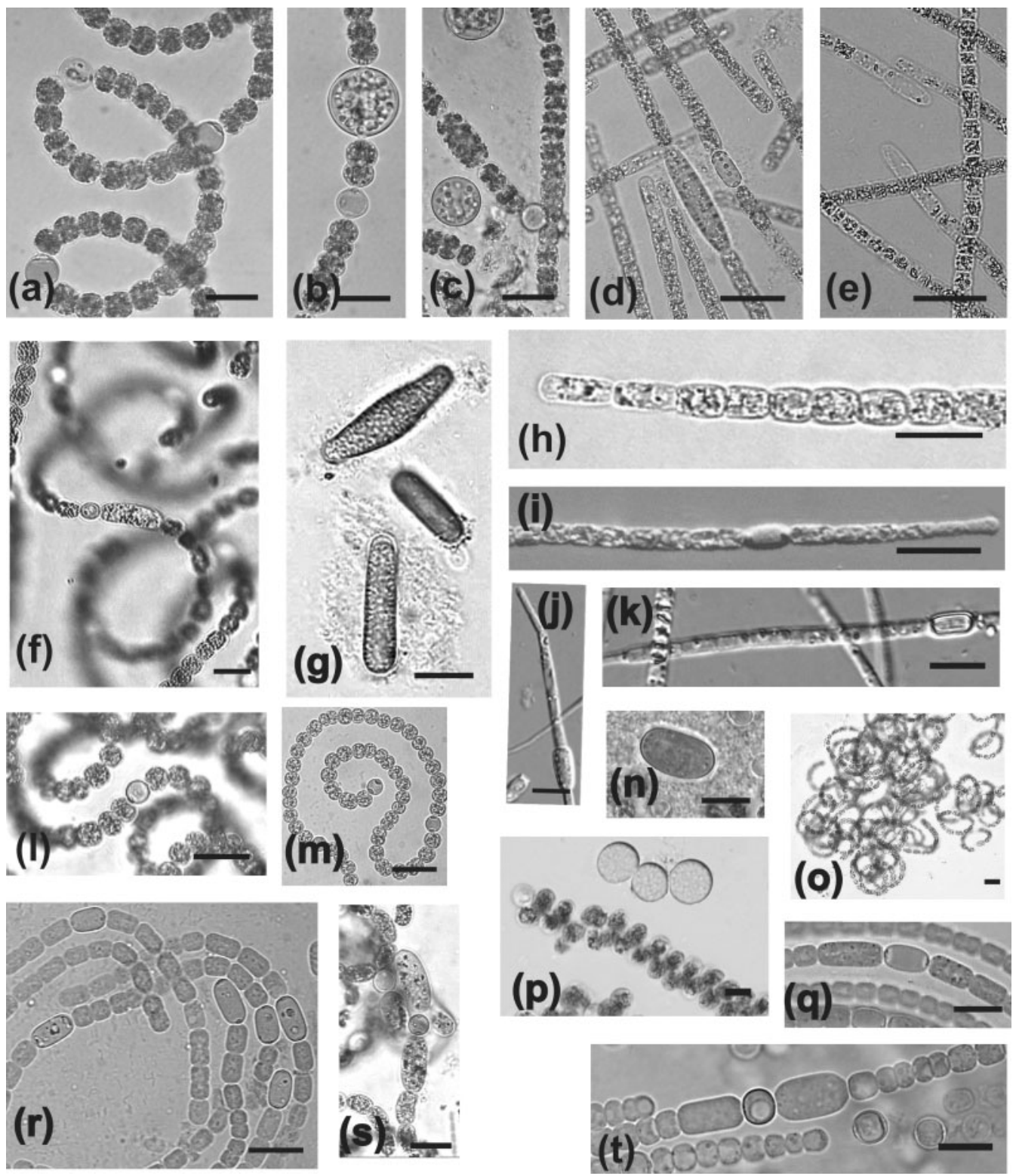

Fig. 1. Microphotographs of some Anabaena and Aphanizomenon strains in phylogenetic cluster 1, showing important features of the strains. (a) Anabaena cf. crassa 1tu27S7; (b) Anabaena planctonica 1tu30s13; (c) Anabaena smithii 1tu39s8; (d) Aphanizomenon flos-aquae 1tu26s2; (e) Aphanizomenon flos-aquae 1tu37S13; (f) Anabaena cf. circinalis var. macrospora 1tu28s13; (g) akinetes of Anabaena cf. circinalis var. macrospora 1tu23s3; (h) Aphanizomenon gracile 1tu26s16; (i) Aphanizomenon gracile 1tu26s16; (j) akinete of Aphanizomenon issatschenkoi 0tu37s7; (k) Aphanizomenon issatschenkoi Otu37s7; (I) Anabaena flos-aquae 1tu33s2a; (m) Anabaena circinalis 1tu30s11; (n) akinete of Anabaena flosaquae 1tu33s2a; (o) Anabaena lemmermannii 1tu32s11; (p) Anabaena compacta ANACOM-KOR; (q) Anabaena oscillarioides BECID23; ( $r$ ) Anabaena cf. cylindrica XP6B; (s) akinete of Anabaena lemmermannii 1tu32s11; ( $\mathrm{t}$ ) Anabaena oscillarioides BECID22. Bars, $10 \mu \mathrm{m}$.

Anabaena strains can be divided into two groups according to their habitats (Table 2). Planktic species had gas vesicles, which were absent in benthic species. Anabaena sp. 1tu34s7, which was isolated from the plankton, did not have gas vesicles and we suspect that it was of benthic origin. In planktic Anabaena strains, trichomes varied from coiled to straight (Fig. 1) and two morphological groups were recognized according to the trichome width. Strains of Anabaena cf. crassa, Anabaena circinalis, Anabaena planctonica, Anabaena spiroides, Anabaena smithii, Anabaena mucosa and Anabaena sigmoidea had significantly $(P<0 \cdot 05)$ wider trichomes, heterocytes and akinetes than strains of Anabaena flos-aquae, Anabaena lemmermannii and Anabaena cf. circinalis var. macrospora (Table 2). 

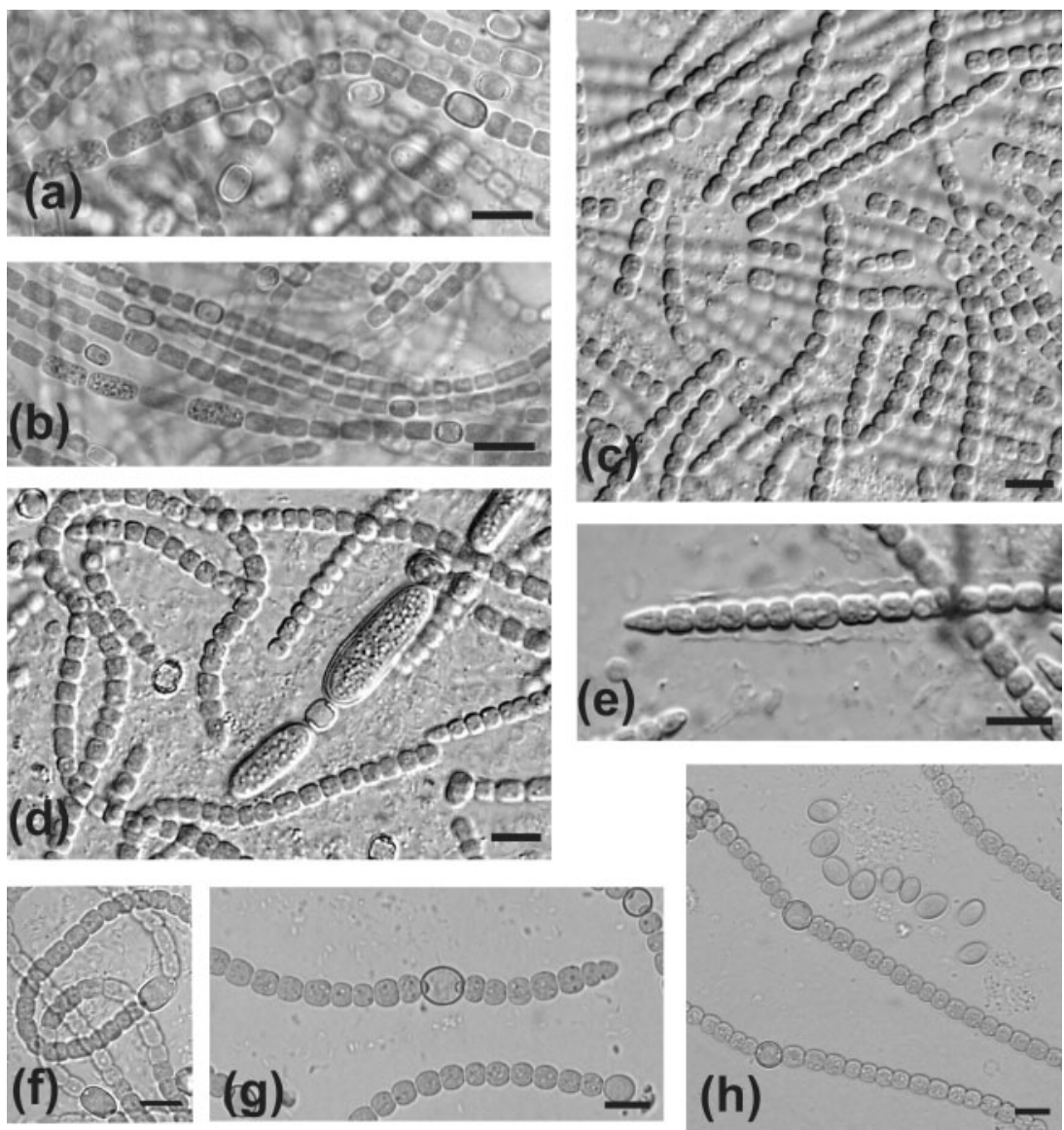

Fig. 2. Microphotographs of some Anabaena and Trichormus strains in phylogenetic clusters 2-6, showing important features of the strains. (a) T. variabilis HINDAK 2001/4; (b) T. variabilis GREIFSWALD; (c) Anabaena cf. oscillarioides BO HINDAK 1984/43; (d) and (e) Anabaena augstumalis SCHMIDKE JAHNKE/4a; (f) T. azollae BAl/1983; (g) and (h) T. doliolum 1. Bars, $10 \mu \mathrm{m}$.
However, some transition types with overlapping values were found (e.g. Anabaena circinalis and Anabaena flosaquae) (Table 2). Benthic Anabaena strains had flexuous trichomes with a diffuse mucilaginous sheath and typical oval morphology of akinetes and terminal heterocytes (Fig. 2).

The genus Trichormus was morphologically variable. The special lenticular-shaped akinetes separated $T$. doliolum from all other investigated strains (Fig. 2h). Both strains of Trichormus variabilis were morphologically similar, with long wavy filaments and apoheterocytic development of akinetes (Fig. 2a, b). Trichormus azollae, a cyanobiont of Azolla fern, was morphologically related to the Nostoc strains. Similarly to some Nostoc strains (N. muscorum, N. ellipsosporum), it formed long, irregularly coiled trichomes surrounded by a diffuse mucilaginous envelope (Fig. 2f). In addition, the type of akinete development (starting from the middle of the filament between two heterocytes) was similar to that of several Nostoc strains. Morphology of the Nostoc strains was previously described by Hrouzek et al. (2003).

Our results indicated that parameters of akinetes were important taxonomic characters. PCA of all morphological characters showed that most of the total variance is attributable to variance in width and length of akinetes (Fig. 3). Moreover, the shape of the akinetes was quite

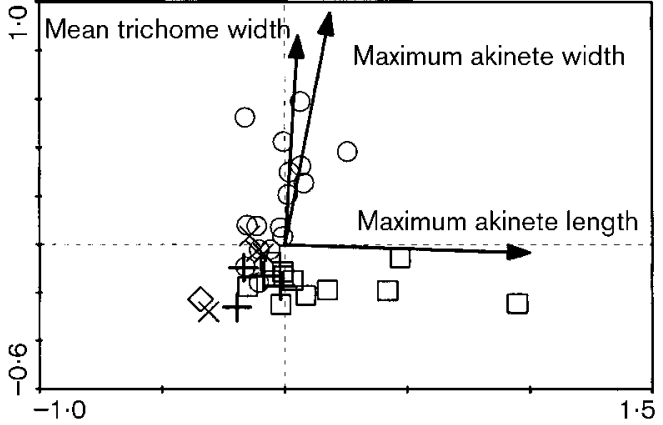

Planktic Anabaena $\square$ Aphanizomenon + Benthic Anabaena XTrichormus $\diamond$ Nostoc
Fig. 3. PCA plot based on the morphological characteristics of studied cyanobacterial strains. The most variable characteristics were length and width of akinetes as well as width of trichomes (shown by the arrows). The first and second principal components accounted for $99 \%$ of the total variance. 


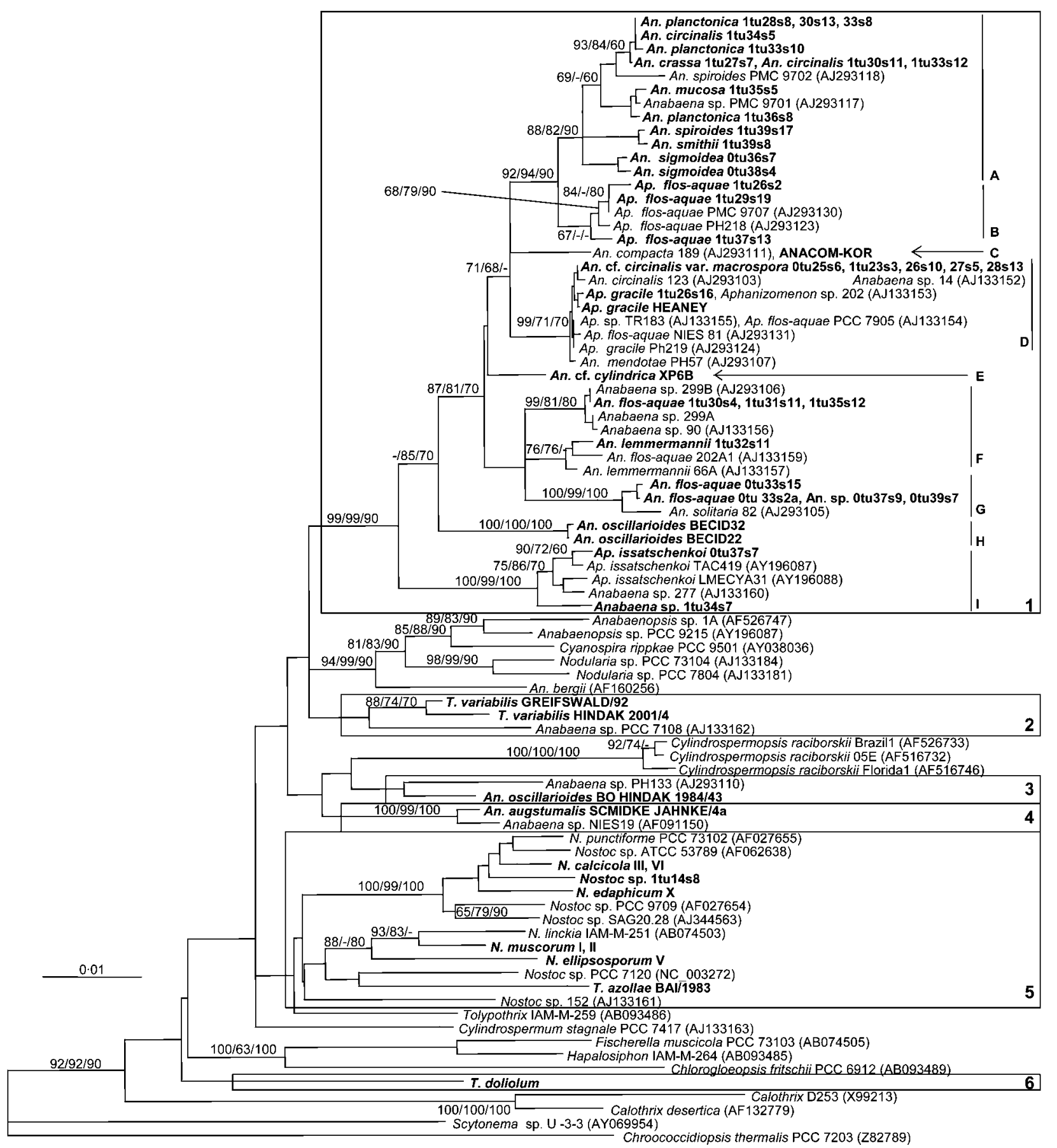

Fig. 4. Neighbour-joining tree based on $16 \mathrm{~S}$ rRNA gene sequences (1393 bp) showing the clustering of studied Anabaena (abbreviated as An.), Aphanizomenon (Ap.), Trichormus (T.) and Nostoc (N.) strains (in bold). Numbers near nodes indicate bootstrap values over $65 \%$ for NJ, MP and ML analyses.

stable. Previously, Stulp \& Stam (1982, 1985) found the position of akinetes, shape of terminal cells and width of vegetative cells to be useful taxonomic characters for Anabaena. These morphological features were retained in different light and temperature conditions (Stulp \& Stam, 1985) and even brackish water conditions (Stulp \& Stam, 1984a).

\section{Genetic relationships of the studied strains}

Six clusters were consistently formed in the analysis of $16 \mathrm{~S}$ rRNA, $r p o B$ and $r b c L X$ genes: cluster 1 contained all planktic Anabaena and Aphanizomenon strains as well as five benthic Anabaena strains; clusters 2, 3, 4 and 6 contained benthic strains T. variabilis, Anabaena oscillarioides 


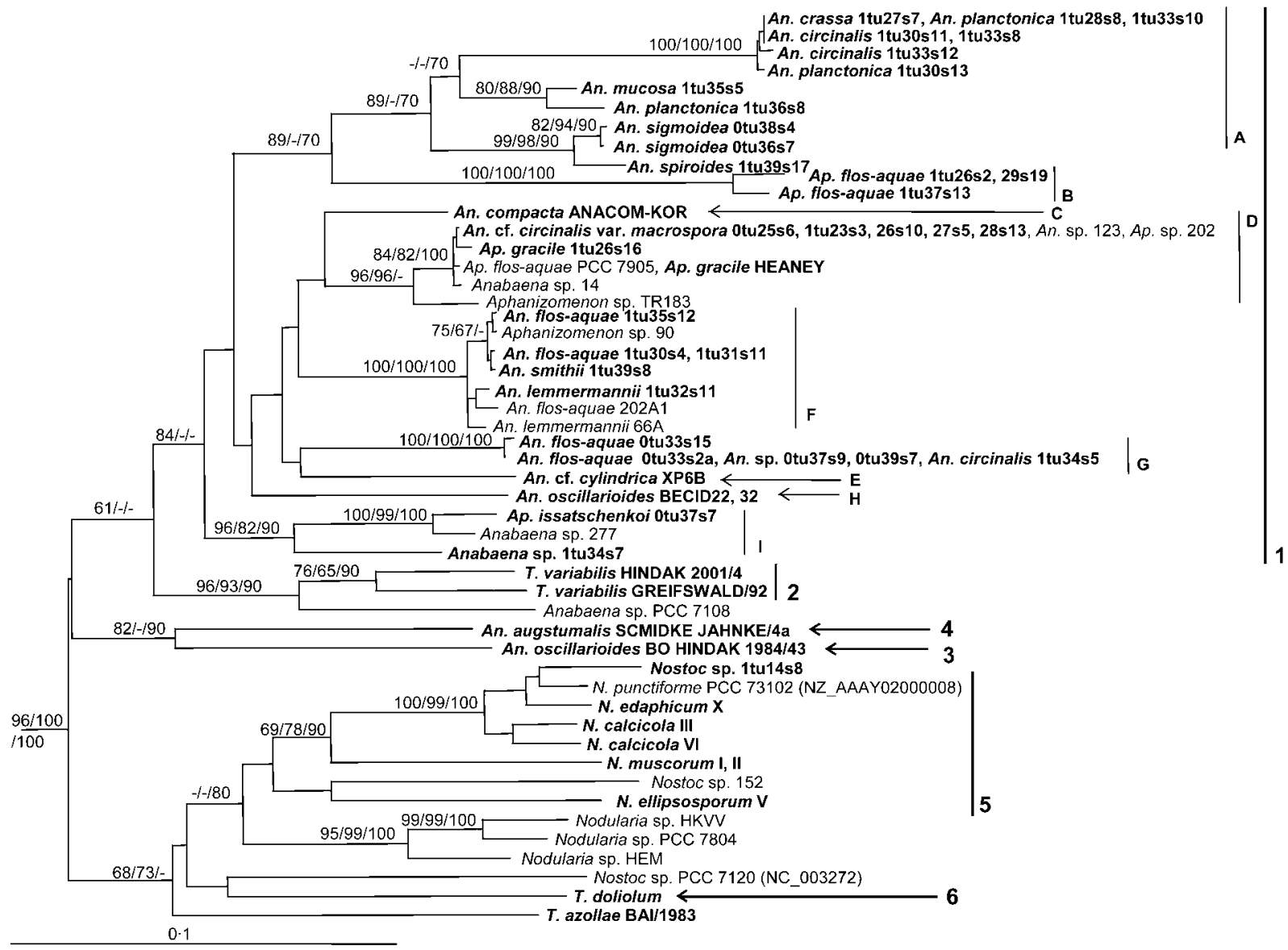

Fig. 5. Neighbour-joining tree based on $r p o B$ sequences ( $451 \mathrm{bp}$ ) showing the clustering of studied Anabaena, Aphanizomenon, Trichormus and Nostoc strains (in bold). Numbers near nodes indicate bootstrap values over $65 \%$ for NJ, MP and ML analyses. The outgroup taxa, Microcystis sp. 130 and Planktothrix NIVA-CYA126, are not shown.

BO HINDAK 2001/4, Anabaena augstumalis and T. doliolum, respectively; and cluster 5 contained all Nostoc strains and T. azollae. The tree topologies were similar with all tree-constructing methods, and therefore only the $\mathrm{NJ}$ tree is presented for each gene (Figs 4, 5 and 6). The overall topology was in agreement for the $16 \mathrm{~S}$ rRNA gene, $r b c L X$ and $r p o B$ trees. However, within closely related Anabaena strains, some differences were found: Anabaena smithii 1tu39s8 clustered with hepatotoxic Anabaena strains in the $r p o B$ tree and Anabaena circinalis 1tu34s5 with Anabaena flos-aquae strains in the $r p o B$ and $r b c L X$ trees instead of subcluster A (Figs 4, 5 and 6). Otherwise, the few conflicting nodes between gene trees received only low bootstrap support. These were generally lower in $r b c L \mathrm{X}$ and $r p o B$ trees than in the 16S rRNA gene tree, probably because of a smaller number of variable bases. Rudi et al. (1998) also found that the topologies of the 16S rRNA gene and $r b c L X$ trees were not congruent for genetically closely related Nostoc and Anabaena strains and stated that this was due to lateral gene transfer between the strains. Nevertheless, in the present study, lateral gene transfer did not seem to play a major role in determining the topologies of gene trees.
Since hierarchical clustering of $16 \mathrm{~S}$ rRNA, $r p o B$ and $r b c L X$ gene sequences did not receive high bootstrap support for all the clusters and subclusters of all gene trees, PCA was performed. All clusters were also found in PCA, confirming the validity of the hierarchical clustering (data not shown). Principal components 1 and 2 together accounted for $84.6 \%$ of the total variance in the $16 \mathrm{~S}$ rRNA distance matrix.

Genetic data did not support the distinction of planktic Anabaena and Aphanizomenon from benthic Anabaena strains as did the morphological data. The benthic Anabaena strains BECID22, BECID32, XP6B, 1tu34s7 and 277, which lack visible gas vesicles, were intermixed with planktic Anabaena and Aphanizomenon strains in 16S rRNA, rpoB and $r b c L X$ gene trees with high bootstrap support (cluster 1 in Figs 4, 5 and 6). Moreover, a 16S rRNA gene tree with the forced monophyly of planktic AnabaenalAphanizomenon strains was significantly worse $(P=0 \cdot 0010-0 \cdot 0013)$ than the original tree in all tests performed. Thus, these tests did not support the separation of planktic and benthic AnabaenalAphanizomenon strains. This finding contradicts 


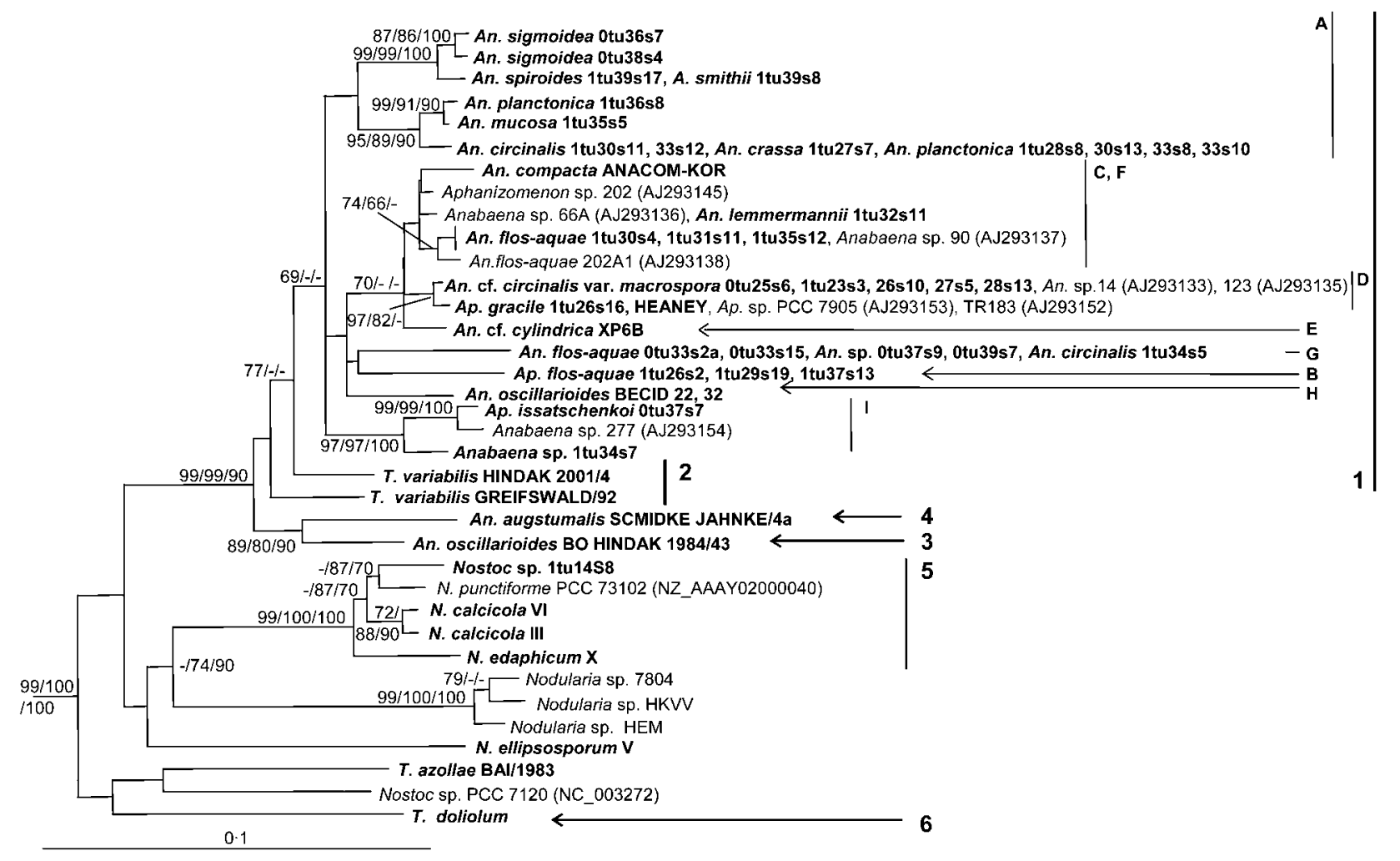

Fig. 6. Neighbour-joining tree based on $r b c L X$ sequences (606 bp) showing the clustering of studied Anabaena, Aphanizomenon, Trichormus and Nostoc strains (in bold). Numbers near nodes indicate bootstrap values over $65 \%$ for NJ, MP and ML analyses. The outgroup taxa, Microcystis sp. 130 (Z94894) and Planktothrix NIVA-CYA126 (Z94873), are not shown.

Iteman et al. (2002), who found a distinct subcluster of planktic heterocytous cyanobacteria with the exception of Cylindrospermopsis. Other benthic Anabaena/Trichormus strains were placed outside cluster 1 , which contained all planktic and five benthic Anabaena as well as all Aphanizomenon strains.

Anabaena and Aphanizomenon strains in cluster 1 were genetically heterogeneous (16S rRNA gene sequence similarity $>94.8 \%$ ) and intermixed in all gene trees (cluster 1 in Figs 4, 5 and 6), confirming the results of earlier studies with other Anabaena and Aphanizomenon strains (Lyra et al., 2001; Gugger et al., 2002b; Iteman et al., 2002). In addition, the monophyly of Aphanizomenon or planktic Anabaena was rejected in all statistical tests $(P=0 \cdot 0001)$. The monophyly of Aphanizomenon strains was proposed in a recent paper of Li et al. (2003), but in that study planktic Anabaena sequences were not included in the analysis.

Cluster 1, containing all planktic and five benthic Anabaena as well as all Aphanizomenon strains, was divided into nine subclusters, which mostly received high bootstrap support in all the gene trees (subclusters A-I in Figs 4, 5 and 6). Morphologically, the strains in this cluster were separated from the other strains including benthic strains in clusters
2-4 by absence of terminal heterocysts. The cut-off points 97.5 and $95 \% 16 \mathrm{~S}$ rRNA gene sequence similarity have been suggested for bacterial species and genus definition, respectively (Stackebrandt \& Goebel, 1994; Ludwig et al., 1998). According to those definitions, the evolutionary distances of this study suggested that the strains in cluster 1 could be divided into two to three species belonging to a single genus (Table 3 ). Cluster 1 could also be divided into more than three species (up to nine) according to the

Table 3. Matrix showing $P$-distances based on the $16 \mathrm{~S}$ rRNA gene (1386 bp) between the subclusters of cluster 1

\begin{tabular}{|lccccccccc|}
\hline Subcluster & A & B & C & D & E & F & G & H & I \\
\hline A & $98 \cdot 6$ & & & & & & & & \\
B & $99 \cdot 1$ & $99 \cdot 4$ & & & & & & & \\
C & $98 \cdot 3$ & $98 \cdot 2$ & 100 & & & & & & \\
D & $98 \cdot 4$ & $98 \cdot 8$ & $98 \cdot 5$ & $99 \cdot 8$ & & & & & \\
E & $98 \cdot 0$ & $98 \cdot 0$ & $98 \cdot 9$ & $98 \cdot 6$ & - & & & & \\
F & $97 \cdot 7$ & $98 \cdot 0$ & $98 \cdot 8$ & $98 \cdot 1$ & $99 \cdot 2$ & $98 \cdot 8$ & & & \\
G & $96 \cdot 8$ & $97 \cdot 0$ & $97 \cdot 4$ & $97 \cdot 6$ & $97 \cdot 9$ & $98 \cdot 4$ & $99 \cdot 4$ & & \\
H & $96 \cdot 5$ & $96 \cdot 8$ & $97 \cdot 4$ & $96 \cdot 9$ & $98 \cdot 2$ & $98 \cdot 0$ & $98 \cdot 0$ & $99 \cdot 9$ & \\
I & $95 \cdot 4$ & $95 \cdot 7$ & $96 \cdot 3$ & $96 \cdot 3$ & $96 \cdot 6$ & $97 \cdot 1$ & $96 \cdot 7$ & $97 \cdot 0$ & $98 \cdot 8$ \\
& & & & & & & & & \\
\hline
\end{tabular}


subclustering of strains in phylogenetic trees and morphological data presented here, although the evolutionary distances between subclusters were $>97.5 \%$. Most of the phylogenetic subclusters found in all the gene trees were also defined by morphological characters. In addition, the evolutionary distances between the subclusters were discontinuous (Table 3 ). The subclustering was also reflected in the length and the sequence of the variable indel region of the $r p o B$ gene and was confirmed in the PCA of the $16 \mathrm{~S}$ rRNA gene (data not shown). In addition, the strains in each subcluster shared a similar denaturing-gradient gel electrophoresis (DGGE) pattern of 16S rRNA gene fragments (450 bp) (unpublished results). The studied strains had from one to six different copies of the 16S rRNA gene according to DGGE analysis. These findings further support the subclustering of AnabaenalAphanizomenon strains. However, the clustering of the studied Anabaena and Aphanizomenon strains did not follow the current classification of the genera. In future, DNA-DNA reassociation studies will be able to give more evidence for relationships of studied strains at the species level. Previously, Stam \& Stulp (1984b, 1985) found in DNA-DNA reassociation studies that the morphology of Anabaena strains was reflected in their genetic relationships. However, our studies indicated that the classification of Anabaena strains might be more complicated.

The highly supported subcluster A contained various planktic Anabaena strains, Anabaena planctonica, Anabaena crassa, Anabaena mucosa, Anabaena spiroides, Anabaena smithii and Anabaena sigmoidea (Figs 4, 5 and 6), which shared relatively high $16 \mathrm{~S}$ rRNA gene sequence similarity ( $>98 \cdot 6 \%$ ). Both irregularly coiled Anabaena strains such as Anabaena circinalis and straight Anabaena species such as Anabaena planctonica strains were included in subcluster A, indicating that coiling of the trichome was not useful for classification of Anabaena morphotypes. The strains were otherwise morphologically relatively similar to each other and to Anabaena strains in subcluster F and G. Nevertheless, a few morphological differences were found between these subclusters. Strains in subcluster A had significantly wider heterocytes, akinetes and trichomes than other Anabaena strains in cluster F and G. Thus, the close relationship and shared morphological features suggest that the strains in subcluster A might be related at the species level.

Aphanizomenon flos-aquae strains were included in subcluster B in all the gene trees, although the bootstrap support was low in MP and ML analysis of the 16S rRNA gene (Figs 4, 5 and 6). These strains were closely related and shared identical $r b c L X$ gene sequences and highly similar $16 \mathrm{~S}$ rRNA $(>99.4 \%)$ and $r p o B(>99.8 \%)$ genes. Also, in the study of Gugger et al. (2002b) a cluster of mainly Aphanizomenon flos-aquae sequences was found in $16 \mathrm{~S}$ rRNA gene and $r b c L X$ trees, but it was not resolved in the ITS tree. The studied Aphanizomenon flos-aquae strains shared several morphological features, e.g. hyaline end cells, long akinetes and originally fascicle-like colonies, which separate these strains from the other Anabaena and also Aphanizomenon strains. The proposed type strain of Aphanizomenon flos-aquae, PCC 7905, did not cluster with the Aphanizomenon flos-aquae strains of this study. However, Rippka et al. (2001b) pointed out that the morphology of the PCC 7905 now in culture does not correspond well with the description of Aphanizomenon flos-aquae. The Aphanizomenon strains TR183 and 202 in cluster D, described previously as Aphanizomenon flosaquae (Gugger et al., 2002b), are called Aphanizomenon sp. in this study, because the original identification of these strains was problematic (Lyra et al., 2001). No morphological description of strain NIES81 was found. Aphanizomenon flos-aquae seems to lose its typical colony structure in laboratory cultivation, which might complicate its identification (Gugger et al., 2002b; this study). However, phylogenetic and morphological data from this study suggest that Aphanizomenon flos-aquae might form its own species.

Anabaena compacta ANACOM-KOR from the Czech Republic shared an identical 16S rRNA gene sequence with the previously described Anabaena compacta strain 189 from Denmark (Gugger et al., 2002b), and these strains formed a distinct cluster, $\mathrm{C}$, in the16S rRNA and rpoB trees (Figs 4 and 5). In the rbcLX analysis, Anabaena compacta ANACOM-KOR was clustered together with hepatotoxic Anabaena strains in cluster F (Fig. 6). Anabaena compacta was easily identified by its solitary, densely and regularly coiled trichomes (Fig. 1) and thus the morphology was in accordance with genetic data. The dense coiling of Anabaena compacta ANACOM-KOR was stable in culture and seems to be characteristic for this species, although the coiling was not a useful feature for the classification of other Anabaena species.

Aphanizomenon gracile and Anabaena cf. circinalis var. macrospora strains were closely related and intermixed in all the gene trees (cluster D in Figs 4, 5 and 6; Table 3). The cluster also included neurotoxic Anabaena strains described by Gugger et al. (2002b) and Lyra et al. (2001). This close relationship between neurotoxic Anabaena and Aphanizomenon strains (PCC 7905, TR183 and 202) had been previously revealed by $16 \mathrm{~S}$ rRNA-RFLP, the $16 \mathrm{~S}$ rRNA gene (Lyra et al., 2001; Iteman et al., 2002), rbcLX and ITS sequencing (Gugger et al., 2002b), as well as by the analysis of cellular fatty acids (Gugger et al., 2002a). The morphological similarity of Aphanizomenon gracile to some Anabaena strains has been discussed previously by Komárek \& Anagnostidis (1989). These strains grow in solitary trichomes which do not have elongated, hyaline or pointed end cells. Surprisingly, all studied strains (Anabaena and Aphanizomenon) included in cluster D had very similar morphology and development of akinetes. They all form cylindrical akinetes by fusion of several vegetative cells next to or distant from a heterocyte. This type of akinete development separates it from other subclusters including planktic Anabaena strains and could 
be used for classification of AnabaenalAphanizomenon species. Previously, the development of akinetes has been found to be a stable character and suggested to have important taxonomic value for Anabaena classification (Stulp \& Stam, 1982, 1985). The morphological similarities and close evolutionary distances suggest that Aphanizomenon gracile and Anabaena strains in cluster D might be assignable to a single species.

Benthic Anabaena cylindrica XP6B was the only representative of subcluster E (Figs 4, 5 and 6). XP6B was actually closely related to the hepatotoxic strains of subcluster $\mathrm{F}$ (16S rRNA sequence similarity $>99 \cdot 2 \%$ ). Morphologically this strain was separated from strains in subcluster $\mathrm{F}$ by a lack of gas vesicles, elliptical vegetative cells and heterocytes as well as presence of diffusive mucilage around trichomes. The benthic strains Anabaena oscillarioides BECID22 and BECID32 of cluster 1 formed subcluster $\mathrm{H}$ in all the gene trees (Figs 4, 5 and 6) and shared $<98.2 \% 16 \mathrm{~S}$ rRNA gene sequence similarity with the other subclusters. These BECID strains were morphologically separable from other subclusters by the absence of gas vesicles, cylindrical akinetes (Fig. 1t) and trichomes arranged in fascicle-like formation with diffusive mucilage. More strains closely related to subclusters $\mathrm{E}$ and $\mathrm{H}$ are needed in order to conclude their morphological similarities and classification. Nevertheless, the close relationship between these benthic Anabaena and planktic AnabaenalAphanizomenon strains indicates that gas vesicles are not a useful feature for classification of Anabaena.

In all gene trees, subcluster $\mathrm{F}$ consists of Anabaena flos-aquae and Anabaena lemmermannii strains, which were potential microcystin producers according to mcyE-PCR. These strains were closely related (16S rRNA gene sequence similarity $>98.8 \%$ ) to each other, but also to non-toxic Anabaena flos-aquae strains of cluster G (16S rRNA gene sequence similarity $>98.4 \%$ ) (Fig. 4 ; Table 3 ). Cluster F received high bootstrap support only in the $r p o B$ analysis (Fig. 5). In the 16S rRNA gene tree, the hepatotoxic strains were divided into two highly supported clusters and in the rbcLX analysis also Aphanizomenon sp. 202 and Anabaena compacta ANACOM-KOR were placed in this cluster (Fig. 6). The close similarity within subcluster F and between it and non-hepatotoxic Anabaena flos-aquae strains indicated that the latter might have recently lost their ability to produce microcystins (Rantala et al., 2004). We were not able to find any morphological criteria to distinguish strains from subclusters $\mathrm{F}$ and $\mathrm{G}$, which mostly contained strains identified as Anabaena lemmermannii and Anabaena flos-aquae. These subclusters could be separated only by the phylogenetic analysis and by the potential hepatotoxin production of the strains in subcluster $\mathrm{F}$ with the exception of a non-toxic strain, Anabaena sp. 299A (this study; Gugger et al., 2002b). Thus, the delineation of morphotypes Anabaena lemmermannii and Anabaena flos-aquae remains to be confirmed.

Interestingly, planktic Aphanizomenon issatschenkoi, 'benthic'
Anabaena sp. 1tu34s7 and Anabaena sp. 277 were grouped together (subcluster I in Figs 4, 5 and 6) and were clearly separated from the other planktic Anabaena and Aphanizomenon strains in all gene trees as well as in PCA. This cluster shared $<96.4 \% 16 \mathrm{~S}$ rRNA gene sequence similarity with other clusters/subclusters, indicating that the Aphanizomenon issatschenkoi strains, Anabaena sp. 277 and 1tu34s7 belong to different species from Anabaena/Aphanizomenon strains in cluster 1 . The cluster was quite heterogeneous morphologically, containing both benthic and planktic strains. The Anabaena strains 1tu34s7 and 277 in this subcluster were isolated from plankton (this study; Lyra et al., 2001) and they might have lost their gas vesicles during cultivation, which has been reported by Rippka et al. (2001b) in the case of PCC 7905. However, gas vesicles were not found in 1tu34s7 soon after isolation, and thus at least 1tu34S7 is probably benthic. It is evident that Aphanizomenon issatschenkoi strains characterized by solitary trichomes with pointed end cells are both morphologically and genetically clearly separated from the other Aphanizomenon strains as well as from typical planktic Anabaena strains. The only observed morphological similarity of strains in cluster I was the shape of akinetes, which were cylindrical in Aphanizomenon issatschenkoi and Anabaena sp. 1tu34s7. Akinetes were not found in Anabaena sp. 277.

Trichormus strains, which were separated morphologically from Anabaena and Aphanizomenon strains by akinete development, were divided into three well-separated clusters, 2, 5 and 6 (Figs 4, 5 and 6), and were not monophyletic. These Trichormus strains were found to be morphologically heterogeneous. Two benthic strains with wavy filaments and apoheterocytic akinete formation were assigned as $T$. variabilis. These $T$. variabilis strains GREIFSWALD and HINDAK/2001/4 also shared a high $16 \mathrm{~S}$ rRNA gene sequence similarity $(99 \cdot 2 \%)$ and formed cluster 2 , which was loosely grouped with Anabaena PCC 7108 (Figs 4 and 5). Also, DNA-DNA reassociation studies of Stulp \& Stam (1984b, 1985) with several Anabaena species support our results that Anabaena (Trichormus) variabilis strains were clearly separated from other Anabaena species. Stulp \& Stam (1984b, 1985) found that relative binding values between Anabaena varibilis and other Anabaena species ranged from 31 to $39 \%$. Interestingly, T. doliolum, which was morphologically separated from other Trichormus strains by shape of akinete, shared less than $95 \cdot 3 \%$ $16 \mathrm{~S}$ rRNA gene sequence similarity with any other cyanobacterial sequence and formed cluster 6 (Figs 4, 5 and 6). This indicates that $T$. doliolum might not be related to Anabaena, Trichormus or Nostoc strains at the species or even genus level if the suggested cut-off point for genus definition, $95 \% 16 \mathrm{~S}$ rRNA gene sequence similarity, is followed (Ludwig et al., 1998). T. azollae BAI/1983 clustered with heterogeneous Nostoc strains (Figs 4, 5 and 6) and might actually belong to the genus Nostoc rather than to Trichormus or Anabaena. Similar results were found in analysis of restriction sites in the nif region (Meeks et al., 
1988). Also, morphological features such as a mucilaginous envelope support the transfer of $T$. azollae to the genus Nostoc.

The benthic Anabaena oscillarioides BO HINDAK 1984/43 and Anabaena augstumalis JAHNKE/4a formed clusters 3 and 4 in the 16S rRNA gene tree (Fig. 4) and these clusters shared $16 \mathrm{~S}$ rRNA gene sequence similarity $<95.5 \%$. In the $r p o B$ and $r b c L X$ gene trees, Anabaena oscillarioides $\mathrm{BO}$ HINDAK 1984/43 and Anabaena augstumalis JAHNKE/4a were grouped together, probably because no other closely related sequences of these genes were available (Figs 5 and 6). These Anabaena strains were morphologically separated from other Anabaena strains in cluster 1 by conical end cells and the presence of terminal heterocytes (Table 2). Among other features, conical end cells were also suggested by Lachance (1981) to separate Anabaena and Nostoc strains. The benthic Anabaena/Trichormus clusters 2-4 were grouped with planktic Anabaenal Aphanizomenon rather than with Nostoc strains (Figs 4, 5 and 6). However, the clustering of all AnabaenalAphanizomenon and $T$. variabilis received high bootstrap support only in the $r b c L X$ tree (Fig. 6). The evolutionary distances between the benthic Anabaena strains BO HINDAK 1984/43, JAHNKE/ 4a and T. variabilis as well as Anabaena/Aphanizomenon strains in cluster 1 were $>95.8 \%$, indicating that these clusters 1-4 are not related at the species level. However, more closely related sequences of benthic Anabaena and Trichormus are needed before their phylogenetic position and classification can be resolved.

Nostoc strains were separated from genera Anabaena and Trichormus with the exception of T. azollae in all gene trees (Figs 4, 5 and 6) and thus supported the distinction between the genera Nostoc and Anabaena, as shown previously in studies of $16 \mathrm{~S}$ rRNA gene sequences (Wilmotte \& Herdman, 2001) and the nifD gene (Henson et al., 2002). This was opposite to the studies of Tamas et al. (2000), which was based on a short fragment of nifH. Nostoc sequences were heterogeneous (sequence similarity $93.9 \%$ for the 16S rRNA gene) at the bases of all the gene trees. This is in agreement with the DNA-DNA reassociation studies of Lachance (1981). Therefore, the studied Nostoc strains may actually represent two different genera. The Nostoc strains were clustered together in the 16S rRNA gene tree with low bootstrap support (Figs 4, 5 and 6), and did not form clusters in the $r b c L X$ and $r p o B$ trees. However, within the Nostoc cluster, sequences of $N$. calcicola, N. edaphicum and Nostoc sp. 1tu14s8 shared high $16 \mathrm{~S}$ rRNA sequence similarity $(97 \cdot 7 \%)$ and clustered together with high bootstrap values in all the gene trees (Figs 4, 5 and 6). These Nostoc strains also shared many common features such as terminal conical heterocytes and narrow, straight hormogonia and were morphologically differentiated from the other studied Nostoc strains (Hrouzek et al., 2003; this study). The high sequence and morphological similarity suggest that $N$. calcicola, $N$. edaphicum and Nostoc sp. 1tu14s8 could be assigned to a single species. In addition, $N$. muscorum and $N$. ellipsosporum were morphologically (Hrouzek et al., 2003) and genetically more closely related to each other than to the other studied Nostoc strains. However, the 16S rRNA gene sequence similarity of these two Nostoc strains and T. azollae to any other strains was $<96.7 \%$, indicating that these strains are not related to each other or to other Nostoc strains at the species level.

\section{Conclusion}

This study indicates that planktic Anabaena/Aphanizomenon and benthic Anabaena were not monophyletic, since the planktic Anabaena and Aphanizomenon as well as five benthic strains in cluster 1 were intermixed. Strains in cluster 1 could be assigned to a single genus according to the genetic data. Cluster 1 could be divided into several (eight or nine) species based on genetic and morphological data, although the 16S rRNA gene sequence similarity between the Anabaena/Aphanizomenon subclusters was above $97 \cdot 5 \%$. Most of these supported phylogenetic AnabaenalAphanizomenon subclusters (A-E and $\mathrm{H}$ ) were found in all the gene trees. Moreover, the strains within the subclusters shared certain morphological features that might be used in classification of the strains at the species level. The subclusters were morphologically separable from each other mainly on the basis of akinete parameters, sometimes in combination with the width of the trichome or potential hepatotoxicity. In contrast, coiling of trichomes, distance between heterocytes or the length of vegetative cells seem not to be useful criteria for separation of the subclusters. Trichormus strains were not monophyletic. T. azollae might belong to the genus Nostoc rather than to Anabaena. T. doliolum possibly forms a separate genus according to evolutionary distances. T. variabilis strains were more closely related to the benthic Anabaena strains than Nostoc strains, although T. variabilis and benthic Anabaena strains in clusters 2-4 were genetically relatively heterogeneous. Therefore, more benthic Anabaena and Trichormus strains need to be studied to confirm their phylogenetic positions. Nevertheless, the shape of end cells and presence of terminal heterocytes were found to be important for discriminating between the benthic Anabaena and T. variabilis in clusters 2-4 from the Anabaena strains in cluster 1 . The phylogenetic relationship of the studied strains did not follow the current taxonomic classification of Komárek \& Anagnostidis (1989) or that of Bergey's Manual of Systematic Bacteriology (Rippka et al., 2001c) and therefore a revision of the taxonomy of these anabaenoid strains is needed.

\section{ACKNOWLEDGEMENTS}

This study was funded by the MIDI-CHIP project (EKV2-CT-199900026), the Enste Graduate School and the Academy of Finland (grant 201576). We thank Dr Jaana Lehtimäki and Matti Wahlsten for isolating strains XP6B, BECID22 and BECID32, Luydmila Saari for purifying and maintaining the strains during the study and Dr Stefano 
Ventura for providing internal 16S rRNA primer sequences. Drs Christina Lyra and David Fewer are thanked for critical reading of the manuscript and helpful comments.

\section{REFERENCES}

Desikachary, T. V. (1959). Cyanophyta part I and II. New Delhi: Indian Council of Agricultural Research.

Edwards, U., Rogall, T., Blöcker, H., Emde, M. \& Böttger, E. C. (1989). Isolation and direct complete nucleotide determination of entire genes. Characterization of a gene coding for $16 \mathrm{~S}$ ribosomal RNA. Nucleic Acids Res 17, 7843-7853.

Felsenstein, J. (1993). PHYLIP (Phylogeny Inference Package) version 3.6c. Distributed by the author. Department of Genetics, University of Washington, Seattle, USA.

Geitler, L. (1932). Cyanophyceae. In Kryptogamenflora von Deutschland, Oesterreich und der Schweiz, vol. XIV. Edited by L. Rabenhorst. Leipzig: Akademische Verlagsgesellschaft (in German).

Gkelis, S., Rajaniemi, P., Vardaka, E., Moustaka-Gouni, M., Lanaras, T. \& Sivonen, K. (2005). Limnothrix redekei (Van Goor) Meffert (Cyanobacteria) strains from Lake Kastoria, Greece form a separate phylogenetic group. Microb Ecol (in press).

Gugger, M. F. \& Hoffmann, L. (2004). Polyphyly of the true branching cyanobacteria (Stigonematales). Int J Syst Evol Microbiol 54, 349-357.

Gugger, M., Lyra, C., Suominen, I., Tsitko, I., Humbert, J. F., Salkinoja-Salonen, M. S. \& Sivonen, K. (2002a). Cellular fatty acids as chemotaxonomic markers of the genera Anabaena, Aphanizomenon, Microcystis, Nostoc and Planktothrix (cyanobacteria). Int J Syst Evol Microbiol 52, 1007-1015.

Gugger, M., Lyra, C., Henriksen, P., Couté, A., Humbert, J.-F. \& Sivonen, K. (2002b). Phylogenetic comparison of the cyanobacterial genera Anabaena and Aphanizomenon. Int J Syst Evol Microbiol 52, 1867-1880.

Henson, B. J., Watson, L. E. \& Barnum, S. R. (2002). Molecular differentiation of the heterocystous cyanobacteria, Nostoc and Anabaena, based on complete nifD sequences. Curr Microbiol 45, 161-164.

Henson, B. J., Hesselbrock, S. M., Watson, L. E. \& Barnum, S. R. (2004). Molecular phylogeny of the heterocystous cyanobacteria (subsections IV and V) based on nifD. Int J Syst Evol Microbiol 54, 493-497.

Hönerlager, W., Hahn, D. \& Zeyer, J. (1995). Detection of mRNA of $n r p M$ in Bacillus megaterium ATCC 14581 grown in soil by wholecell hybridisation. Arch Microbiol 163, 235-241.

Hrouzek, P., Šimek, M. \& Komárek, J. (2003). Nitrogenase activity (acetylene reduction activity) and diversity of six soil Nostoc strains. Arch Hydrobiol Suppl 146, 87-101.

Iteman, I., Rippka, R., Tandeau de Marsac, N. \& Herdman, M. (2002). rDNA analyses of planktonic heterocystous cyanobacteria, including members of the genera Anabaenopsis and Cyanospira. Microbiology 148, 481-496.

Kishino, H. \& Hasegawa, M. (1989). Evaluation of the maximum likelihood estimate of the evolutionary tree topologies from DNA sequence data and the branching order in Hominoidea. J Mol Evol 29, 170-179.

Komárek, J. \& Anagnostidis, K. (1989). Modern approach to the classification system of Cyanophytes 4 - Nostocales. Arch Hydrobiol Suppl 82, 247-345.

Komárek, J. \& Kováčik, L. (1989). Trichome structure of four Aphanizomenon taxa (Cyanophyceae) from Czechoslovakia, with notes on the taxonomy and delimitation of the genus. Plant Syst Evol $164,47-64$.

Kotai, J. (1972). Instructions for preparation of modified nutrient solution Z8 for algae. Norwegian Institute for Water Research publication B-11/69, pp. 1-5. Oslo: NIWR.

Lachance, M. (1981). Genetic relatedness of heterocystous cyanobacteria by deoxyribonucleic acid-deoxyribonucleic acid reassociation. Int J Syst Bacteriol 31, 139-147.

Lehtimäki, J., Lyra, C., Suomalainen, S., Sundman, P., Rouhiainen, L., Paulin, L., Salkinoja-Salonen, M. \& Sivonen, K. (2000). Characterization of Nodularia strains, cyanobacteria from brackish waters, by genotypic and phenotypic methods. Int J Syst Evol Microbiol 50, 1043-1053.

Lepère, C., Wilmotte, A. \& Meyer, B. (2000). Molecular diversity of Microcystis strains (Cyanophyceae, Chroococcales) based on $16 \mathrm{~S}$ rRNA sequences. Syst Geogr Plant 70, 275-283.

Li, R., Carmichael, W. W. \& Pereira, P. (2003). Morphological and 16S rRNA gene evidence for reclassification of the paralytic shellfish toxin producing Aphanizomenon flos-aquae LMECYA 31 as Aphanizomenon issatschenkoi (Cyanophyceae). J Phycol 39, 814-818.

Ludwig, W., Strunk, O., Klugbauer, S., Weizenegger, M., Neumaier, J., Bachleither, M. \& Schleifer, K. H. (1998). Bacterial phylogeny based on comparative sequence analysis. Electrophoresis 19, 554-568.

Lyra, C., Suomalainen, S., Gugger, M., Vezie, C., Sundman, P., Paulin, L. \& Sivonen, K. (2001). Molecular characterization of planktic cyanobacteria of Anabaena, Aphanizomenon, Microcystis and Planktothrix genera. Int J Syst Evol Microbiol 51, 513-526.

Meeks, J. C., Joseph, C. M. \& Haselkorn, R. (1988). Organization of the nif genes in cyanobacteria in symbiotic association with Azolla and Anthoceros. Arch Microbiol 150, 61-71.

Posada, D. \& Crandall, K. A. (1998). MODELTEST: testing the model of DNA substitution. Bioinformatics 14, 817-818.

Prager, E. M. \& Wilson, A. C. (1988). Ancient origin of lactalbumin from lysozyme: analysis of DNA and amino acid sequences. $J \mathrm{Mol}$ Evol 27, 326-335.

Rantala, A., Fewer, D. P., Hisbergues, M., Rouhiainen, L., Vaitomaa, J., Börner, T. \& Sivonen, K. (2004). Phylogenetic evidence for the early evolution of microcystin synthesis. Proc Natl Acad Sci U S A 101, 568-573.

Rippka, R., Deruelles, J., Waterbury, J. B., Herdman, M. \& Stanier, R. Y. (1979). Generic assignments, strain histories and properties of pure cultures of cyanobacteria. J Gen Microbiol 111, 1-61.

Rippka, R., Castenholz, R. W. \& Herdman, M. (2001a). Subsection IV. (Formerly Nostocales Castenholz 1989b sensu Rippka, Deruelles, Waterbury, Herdman and Stanier 1979). In Bergey's Manual of Systematic Bacteriology, 2nd edn, vol. 1, pp. 562-566. Edited by D. R. Boone \& R. W. Castenholz. New York: Springer.

Rippka, R., Castenholz, R. W., Iteman, I. \& Herdman, M. (2001b). Form-genus I. Anabaena. In Bergey's Manual of Systematic Bacteriology, 2nd edn, vol. 1, pp. 566-568. Edited by D. R. Boone \& R. W. Castenholz. New York: Springer.

Rippka, R., Castenholz, R. W., Iteman, I. \& Herdman, M. (2001c). Form-genus III. Aphanizomenon Morren 1838. In Bergey's Manual of Systematic Bacteriology, 2nd edn, vol. 1, pp. 569-570. Edited by D. R. Boone \& R. W. Castenholz. New York: Springer.

Rudi, K., Skulberg, O. M. \& Jakobsen, K. S. (1998). Evolution of cyanobacteria by exchange of genetic material among phyletically related strains. J Bacteriol 180, 3453-3461.

Saitou, N. \& Nei, M. (1987). The neighbor-joining method: a new method for reconstructing phylogenetic trees. Mol Biol Evol 4, 406-425.

Stackebrandt, E. \& Goebel, B. M. (1994). Taxonomic note: a place for DNA-DNA reassociation and 16S rRNA sequence analysis in 
the present species definition in Bacteriology. Int J Syst Bacteriol 44, 846-849.

Stanier, R. Y., Kunisawa, R., Mandel, M. \& Cohen-Bazire, G. (1971). Purification and properties of unicellular blue-green algae (order Chroococcales). Bacteriol Rev 35, 171-205.

Stulp, B. K. \& Stam, W. T. (1982). General morphology and akinete germination of a number of Anabaena strains (Cyanophyceae) in culture. Arch Hydrobiol Suppl 63, 35-52.

Stulp, B. K. \& Stam, W. T. (1984a). Growth and morphology of Anabaena strains (Cyanophyceae, Cyanobacteria) in cultures under different salinities. Br Phycol J 19, 281-286.

Stulp, B. K. \& Stam, W. T. (1984b). Genotypic relationships between strains of Anabaena (Cyanophyceae) and their correlation with morphological affinities. Br Phycol J 19, 287-301.

Stulp, B. K. \& Stam, W. T. (1985). Taxonomy of the genus Anabaena (Cyanophyceae) based on morphological and genotypic criteria. Arch Hydrobiol Suppl 71, 257-268.

Swofford, D. L. (2003). PAUP*. Phylogenetic Analysis Using Parsimony (*and other methods). Version 4b10. Sunderland, MA: Sinauer Associates.

Tamas, I., Svircev, Z. \& Andersson, S. G. (2000). Determinative value of a portion of the nifH sequence for the genera Nostoc and Anabaena (cyanobacteria). Curr Microbiol 41, 197-200.

Templeton, A. R. (1983). Phylogenetic interface from restriction endonuclease cleavage site maps with particular reference to the evolution of humans and the apes. Evolution 37, 221-224. ter Braak, C. J. F. \& Šmilauer, P. (1998). CANOCO Release 4. Reference manual and user's guide to Canoco for Windows: Software for Canonical Community Ordination. Ithaca, NY: Microcomputer Power.

Turner, S. (1997). Molecular systematics of oxygenic photosynthetic bacteria. Plant Syst Evol (Suppl.) 11, 13-52.

Turner, S., Pryer, K. M., Miao, V. P. W. \& Palmer, J. D. (1999). Investigating deep phylogenetic relationships among cyanobacteria and plastids by small subunit rRNA sequence analysis. $J$ Eukaryot Microbiol 46, 327-338.

Wilmotte, A. (1994). Molecular evolution and taxonomy of the cyanobacteria. In The Molecular Biology of Cyanobacteria, pp. 1-25. Edited by D. A. Bryant. Dordrecht: Kluwer Academic.

Wilmotte, A. \& Herdman, M. (2001). Phylogenetic relationships among the cyanobacteria based on 16S rRNA sequences. In Bergey's Manual of Systematic Bacteriology, 2nd edn, vol. 1, pp. 487-493. Edited by D. R. Boone \& R. W. Castenholz. New York: Springer.

Zapomělová, E. (2004). Morfologická variabilita a rưst vybraných kmenů sinic rodu Anabaena a Aphanizomenon $v$ závislosti na podminkách prostredí [Morphological variability and growth of chosen cyanobacterial strains of genera Anabaena and Aphanizomenon in the dependence on environmental conditions]. MSc thesis, University of South Bohemia, Czech Republic (in Czech).

Zehnder in Staub, R. (1961). Ernährungphysiologish-autökologische Untersuchung an der planktonischen Blaualge Oscillatoria rubescens DC. Schweiz Z Hydrol 23, 82-198 (in German). 